\title{
Violence, Faith, and Women in Romanian Literature
}

\author{
Giti, CHANDRA, \\ Associated Scholar PhD., United Nations University, Gender Equality Studies and Training Dept, \\ $3^{\text {rd }}$ Floor, Gimli, University of Iceland, Saemundargata 3, 101 Reykjavik, Iceland \\ gitichandra@gmail.com \\ Sanda-Marina, BĂDULESCU, \\ Professor PhD., "Dimitrie Cantemir" Christian University of Bucharest, \\ 176, Splaiul Unirii, District 4, Bucharest \\ sbadules@gmail.com
}

\begin{abstract}
This essay offers a gendered reading of the confluence of violence and faith in Romanian literature, through a reading of two texts: Tatiana Bran's "Deadly Confession", and Elie Wiesel's "Night". While the former looks at the violence visited upon women in the context of religion and faith, the latter seeks to locate the place of women in the course of the loss of faith in a male context. The essay embeds these readings within the larger context of women and violence in Romanian literature from the $19^{\text {th }}$ century to the present. While the instance of Bran's novel serves as representative of much of this literature, the example of Wiesel's autobiographical narrative is uniquely contextualized by the field of Holocaust literature. Nevertheless, it is possible to see these two readings - one, a woman authored text of violence against women, the other, a male authored text of women as a refuge from violence - as complementing each other in the ways in which women respond to faith and the loss of faith.
\end{abstract}

Keywords: women, violence, faith, Holocaust Studies, Romanian literature

JEL Classification: N3, Z1.

\section{Part I}

\section{Introduction}

"Literature opens new perspectives on ways of thinking, living, values, conflicts, myths, self-images and images about the other, through fictional or real characters, in a story from a social and cultural context in which the author is anchored." (lorga, 1940) as the great Romanian historian Nicolae lorga stated. 
Of course, a file of patterns of violence against women has begun and been registered since prehistoric times through many other means that have served to great a collective memory and imagery.

Our paper will entail several models from $19^{\text {th }}, 20^{\text {th }}$ and $21^{\text {st }}$ century literature from the traditional Romanian spaces, to the modern narratives of the Holocaust. The novellas under scrutiny offer several possible realities.

\section{Abused Women in Romanian Space}

\subsection{Last centuries Romanian literature}

Some researches (Asay et al., 2014) reveal that Romania literature stands high in terms of violence and anthropologists (Du, 1986) stress particularly on rural violence.

Romania is still a "man's country" as writer Lucian Boia states, just as the West was until recently, and still is to some extent (Boia, 2006). While women are active and present in almost all fields of activity, they remain somewhat in the shadow of the men.

In the Romanian literature of the $19^{\text {th }}$ and $20^{\text {th }}$ centuries, the woman was treated as " a provider of dowry, two working hands and a children maker", as the Romanian literary critic George Calinescu concluded (Călinescu, 1982).

In Transylvania county of Romania of the $19^{\text {th }}$ century, the writer loan Slavici shows such a cruel reality in unforgettable pages (Slavici, 2007):

- "The suitors do not crave her but her dowry." So, the female character called Sanda was going through the cooler when she found out which of the suitors how much he wanted.

- "Only she knew how many beatings she eats from her husband, a sworn drunk." The condition of the woman is one lacking the freedom with which man is born. On the one hand, it is subordinated to the authority of the man and the victim of his passion for alcohol and physical violence, on the other hand she is limited by the authority and prejudices of her family.

- "I was only 18 years old when I got weak of him, an old Holt who was twenty-six years older than me and could be my father", said the same young women.

Old patriarchal definitions of the female as belonging in the home went through a re-evaluation in the 19th century in Romania. Confused women, 
reacting to the new equalitarian ideals, found themselves questioning and worrying about their tasks and roles (Satir, 1983).

Centuries after centuries in the Transylvanian rural communities, the woman's right to life has been buried with the deceased husband. The widowed woman remained isolated, marginalized by the community. She was harshly sanctioned if she did not live in mourning. She was suspected that she wanted to waste the wealth gathered by her late husband and his family (Bolovan, 2001).

Mara's portrait made by Slavici in the $19^{\text {th }}$ century is one of the most representative one from this point of view. Mara does not even consider that her daughter might become a nun because of the marriage was seen as a heaven of safety in spite of the fact that women relied on men.

There are numerous and complex links between Romanian, Greek, Italian literary texts from the point of view of a miserable widow suffering from the social point of view after the death of his husband. It shows a common area of culture, civilization and belief. Texts could explain other texts through intertextual mechanisms, and they also correspond to some other texts from another region or county, because they explain the reality that generated them. It is the case of a nowadays text written by Tatiana Niculescu Bran, who made the portrait of an abused young women from the rural space of Moldavia, a NorthEast county of Romania.

If Mara did not believe in god as an emancipated woman from the $19^{\text {th }}$ century, in the $21^{\text {st }}$ century the last hope for a young orphan named Irina Cornici is to become a nun, but her choice proved to be the worst one, provoking her death.

\subsection{Recent time Romanian literature}

Tatiana Bran is one of the young Romanian writers who has the courage to put on paper vivid ideas on the tragic women destinies based on violence and misunderstanding in an unfriendly social environment.

Her well known novel "Spovedanie la Tanacu" / "Deadly Confession", followed by "Judges' Book", is a veritable non-fictional document on the tragic destiny of a young orphan women in the modern time. Irina's tremendous short life is described like in a report recording illicit or illegal facts produced by exacerbating the faith in God. 
The events are quite recent, telling to the wide audience a terrible story and a cruel destiny placed in a North-East county of Romania, in 2005.

Irina is a young nun, without her will converted to monastic life, who dies after a failed or perhaps even illegal exorcism (it is somewhat difficult to catalog this event), a said the event that shook the Romanian society. A girl out of a children's home finds her refuge in the monastic settlement of Tanacu, on a hillside away from civilization.

Irina chooses this place from the desire to be with her dear friend, Chita, who accompanied her throughout her life in state institutions for children left without parental care. But it appears in a totally different light, obedient, obedient and profoundly religious, which frightens Irina and gives her cause for suspicion.

Arrived in the monastic place, the girl is subjected to the ritual of confession, which also manages to deeply confuse her, shaking the factors of the appearance of a mental illness. The whole work is a painful enumeration of the girl's anguish, which both the doctors and the abbot of the monastery brought to a predictable and tragic end.

Tatiana Bran's book is not a simple novel, it rather belongs to the investigative journalism category. It is for sure that the emotional substrate has served this selection of the literary category, and her book frightens, giving cold shivers to some passages, raising harsh questions about religion and fanaticism: How far can the Church's hand go to deciding human destiny?

Her novel and her character inspired the film director Cristian Mungiu who produced the film Beyond the Hills. The film won the award for the best screenplay at the 2012 Cannes Film Festival. In 2007 a stage version of the books directed by the American-Romanian director Andrei Serban was performed at La MaMa Theatre in New York. In 2008, the theatre performance was staged in Paris at the Béhague Palace.

The author presents ordinary people in unusual situations. Emphasis is placed on the disorientation of the female character, for orphans do not have a clear orientation and guidance in society for a normal and well-deserved integration. Irina Cornici has a depth resulting from a bitter experience of life woven by a kind of personal guiding. This is interesting, beautiful, full of feminine collective intelligence.

All the characters are taken by the wave of events that they do not understand, which happen to them in real life, and they do not know what to do, living a situation without the exit or the imminent tragic end. 
The exorcism is not only a great outburst of spooky effects (Irina is linked to a cross with her mouth gagged, closed in a cell, without food and water for 3 days), it is not a description of the exorcism in which to tremble while reading it It is a speech about good intentions that lead to a disastrous outcome. It is a general misunderstanding of the other represented by the female character, and the final result is the death of the young woman, incomprehensible and cheated by the nuns. It's an exciting, impressive portrait that makes you think.

The portrait of Irina represents a certain perception of a Romanian, namely Moldovan woman, about the life and the world, marked by a sort of resignation, unwavering acceptance and fatalism that we subtle in the novel "Deadly confession" of Tatiana Bran. There are no guilty indications and no solutions are indicated. Nothing hurts or caricatures, but shows a true reality.

There is similarity between Irina Cornici's tragic ending and that of Anneliese Michel, the heroine of two occidental movies - "Emily Rose's Exorcism" and "Requiem". If Anneliese Michel is a case of possession, the young woman Irina Cornici is a case of ignorant, ill-treated, and misinterpreted illness. In the case of Anneliese, the Catholic priest was assisted by a psychiatrist, and the exorcism sessions were recorded and became evidence in the trial, which is not done to us because there is no clear rule about these procedures. The background was that physicians did not even know how to do more. In the Romanian story, ignorance, fear, confusion, dilettantism paralyzed the case.

\section{Discussion, and Conclusions of Part I}

Unlike the means of manifestation of violence in urban areas, the rural violence like in the small village of Tanacu stem from atavist inheritance, many times being merely an interface of some links, relations and customs almost forgotten. On the other hand, rural violence in Romanian settings is quickly consumed, being an explosion without a retort

But an open conclusion could be that nowadays we do need smart readers, ready to give up all kind of prejudices!

\section{Part II}

While there have been several gendered readings of Holocaust literature, Elie Wiesel's Night is usually read against The Diary of Anne Frank, where it is seen as being primarily male centred, while the Diary is seen as being more women centred. However, very little critical light has been cast on the 
relationship between religion and faith and gender. The following is a reading of the loss of faith as narrated in Night, and its relationship to gender, in a narrative that is largely focuses on the father son bond, even while it is dedicated to the little girl, Tzipora.

There are very few instances in Elie Wiesel's Night in which the women in his life are mentioned. In his account of Moishe, he mentions briefly that Tzipora is the youngest of the children, and that by 1942, his mother is beginning to look for a match for Hilda. In the course of the narrative, women appear marginally, mostly as ciphers of the prevailing conditions: a german officer gifts "Mrs Kahn" a box of chocolates, and everyone assumes that the germans are gentle occupiers; Wiesel's mother is cooking in the kitchen, the "weather is sublime", and all is right with the world. Even as the crackdown begins and defensive measures are taken, a stoicism remains: "My father went down to the cellar and buried our savings. As for my mother, she went on tending to the many chores in the house. Sometimes she would stop and gaze at us in silence." A little later, as foreboding sets in: "I have a bad feeling," said my mother. "This afternoon I saw new faces in the ghetto. Two German officers, I believe they were Gestapo. Since we've been here, we have not seen a single officer..." (Report CEDAW, 2000) As the people of Sighet prepare to be transported out of the ghetto, the poignancy and surreality of the moment is marked by the tender touch that awakens a wife, and the women "boiling eggs, roasting meat, preparing cakes, sewing backpacks" (Tracy, 1996). And when a child cries out, "Water, Mother, I am thirsty!" (Wiesel, 2000) a note is struck which will remind us of the suffering Christ on the Cross.

An interesting reversal comes as the family is being herded out of their homes: "My father was crying. It was the first time I saw him cry. I had never thought it possible. As for my mother, she was walking, her face a mask, without a word, deep in thought. I looked at my little sister, Tzipora, her blond hair neatly combed, her red coat over her arm: a little girl of seven. On her back a bag too heavy for her. She was clenching her teeth; she already knew it was useless to complain." (Wiesel, 2000)

As his father breaks down, all those men who had been the pillars of strength and fortitude, planning, organizing, protecting the women and children, all that male source of strength seems to break along with his father, and the women are left as symbols, if not sources, of perseverance and stoicism. Wiesel recounts how his "sisters lit a fire. Despite her fatigue, my mother began to prepare a meal. We cannot give up, we cannot give up, she kept repeating." Interestingly, it is Maria, their former maid, who comes crying to find them and offer them shelter in her village. This moving of images of strength from male to 
female coincides with a turning point in the young Elie's world, in his religion and its ability to understand and forgive: "That was when I began to hate them [the Hungarian police]," Wiesel says, "and my hatred remains our only link today."

Then, the suppressed agony and fear of the long train journey is piercingly depicted in the possessed screaming and visions of "a woman among us, a certain Mrs Schachter" (Wiesel, 2000). Her wild shrieking is a wordless articulation of the forebodings of the people crammed into the carriage, even as her hallucinations of devouring fires are both prescient, and symbolic of the terrible fire in which the SS throws children - marking the point at which the faith of the young Wiesel finally snaps. The desperate attempts to silence the shrieking woman - beating her, gagging her, shouting at her to stop - and the clinging, pleading, and finally silent child, are both literally as well as figuratively faithful to the traumatized state of the people in the train. And finally:

"We jumped out. I glanced at Mrs. Schächter. Her little boy was still holding her hand. In front of us, those flames. In the air, the smell of burning flesh. It must have been around midnight. We had arrived. In Birkenau." (Wiesel, 2000).

As their worst fears are realized, and the women divided from the men, the young Wiesel's last vision of the women of his family is of his mother holding the little girls hand, stroking her hair "as if to protect her" (Wiesel, 2000).This vision is complemented by his walking into the camps with his father holding his hand. The question of whether the male bond is as protective and strength giving as the female is left open and unspoken. Although we can see that no hand strokes his head protectively, it is also left to the reader's imagination as to whether the young Wiesel derives any sense of protection from holding his father's hand. All we are told is "My hand tightened its grip on my father. All I could think of was not to lose him. Not to remain alone." (Wiesel, 2000) The inmate questioning them as they enter provides a realistic foil to the hallucinating Mrs Schachter, pointing to the chimneys and smoke, railing at them for not believing - "in 1944!" (Wiesel, 2000) - what they had heard about the fate awaiting transported Jews.

Hereafter, the text focuses almost solely on men, given that the men are separated from the women, and the bulk of the remaining experience the Elie Wiesel has in the camps is that of being surrounded by men. The brutality of the camps is embedded in the maleness of the perpetrators and the victims, as is the lack of solace or strength. No man their can offer the men around him comfort or protection - that sense of being protected, by religion and faith, or by one's 
parents, is gone with the last vision of his mother's hand on his sister's head. Instead, watching his father being emasculated, denied dignity and manhood by the camp guards, and not being able to do anything to help him, results in a sort of emasculation of the fifteen year old Wiesel.

Interestingly, when men speak of God and the reasons for keeping their faith in God's plan for them, Wiesel remembers his mother and Tzipora, wondering if they are alive. It is the only time they are mentioned, and the connection is unmistakable. It is as if some memory and hope for his mother and sister functions as a hope against hope when all hope has been lost. Such is the power of the images of women that have been imbued with stoicism, strength, and protection, in the early pages of the text, that even in the absence of any women in the rest of the narrative, the images of women retain the faith when faith has vanished. Ironically, even German girls protect Wiesel; as he recounts the guards' flirting with them, he says "At least, during all that time, we endured neither shouting nor blows." (Wiesel, 2000). Similarly, the French girl who wipes his forehead and comforts him after he has been badly beaten up, calls him "brother", and offers him the comfort of hope for a future when all this will be behind him. And, indeed, he meets her in a time of peace, many years later, in a train in Paris, where they recognize each other - indicating that the hope and protection women symbolize is real, and not does not vanish and prove delusional in the way that faith has seemed to do.

As the narrative nears its end, it is, indeed, his father who provides Wiesel with perseverance and fortitude, but that is because it is now Wiesel who is the source of strength and protection. "My father's presence was the only thing that stopped me. He was running next to me, out of breath, out of strength, desperate. $86 \mathrm{I}$ had no right to let myself die. What would he do without me? I was his sole support." This sense of being the protector for his father is extremely important as the narrative moves on through the long march, in which Wiesel recounts stories of sons running past failing fathers in order to be rid of them, and sons beating their fathers to death for a last crust of bread. The rest of the narrative follows the slow, excruciating, dying of Wiesel's father, its pathos and agony standing both literally and figuratively for the death of humanity and hope.

\section{Discussions and Further Developments of Part II}

Even though this text is seen most often in the context of being more male signature than, for instance, The Diary of Anne Frank, the presence of women is both significant and illuminating. They are both literally, as well as 
figuratively, sources of strength and protection in an environment where the traditional sources of strength and protection - men - are shown to be attacked, vulnerable, human, weak. Whether this can be seen as typifying women in their stereotypical roles as nurturing, maternal, symbolic figures or not, can certainly be debated, but it is worth noting that the autobiographical nature of the narrative casts them as real, rather than merely symbolic figures. Equally, in the larger context of Holocaust, Trauma, and Violence, studies, gender is a wide open area, where very few things can be taken as established.

\section{The final Questions of the essay:}

Is the literature reflecting a reality or it is fiction?

Is the literature source of influence for the real behaviour of men and women?

\section{References}

[1] Asay, S. \& DeFrain, J. \& Metzger, M., \& Moyer R. (2014) Family Violence from a Global Perspective. A Strengths - Based Approach. Los Angeles, London, New Delhi, Singapore, Washington DC: Sage Publications.

[2] Boia, L. (2006) Pentru o istorie a imaginarului. Bucharest: Humanitas Press.

[3] Bolovan, S. (2001) Aspects Regarding the Status of the Woman in the Transylvanian Romanian Village during the Modern Times. Trans. $R, 10$, no. 3, pp. 3-11.

[4] Buttsworth, Sara, and Abbenhuis, Maartje M. (2010). Monsters in the Mirror: Representations of Nazism in Post-war Popular Culture (Praeger: Santa Barbara)

[5] Călinescu, G. (1982) Istoria literaturii române de la origini până în prezent. Bucharest: Minerva Press.

[6] CEDAW Report, (2000). Women's Status in Romania. A Shadow Report to the CEDAW 23rd Session (2000). Web page. Retrieved from http://www.legislationline.org/documents/id/7703

[7] Du Boulay, J. (1986) Women Images of Their Nature and Destiny in Rural Greece. In Gender and Power in Rural Greece. New Jersey: Princeton University Press.

[8] Fisher, Jerilyn, and Siber, Ellen S, eds. Boyhood Unraveled: Elie Wiesel's Night (1960), by Sarah R Horowitz, in Women in Literature: Reading Through the Lens of Gender (Greenwood Press, London) 2003.

[9] Iorga, N. (1940). Ce este sud-estul european?. Bucharest: Romanian Digital Library.

[10] Lagerwey, Mary D (1996). "Reading Anne Frank and Elie Wiesel: Voice and Gender in Stories of the Holocaust". (Contemporary Jewry, January 1996, Volume 17, Issue 1, pp 48-65) 
[11]Leard, Layla Dawn, (2017) "Chimneys in the Night: A Comparative Analysis of Elie Wiesel's Night and Olga Lengyel's Five Chimneys". (Mount Royal Undergraduate Humanities Review, Vol 4, 2017).

[12]Satir, V. (1983) Conjoint family therapy. Palo Alto, CA: Science and Behavior Books.

[13]Slavici, I. (2007) Opere alese. Bucharest: Steaua Nordului Publishing House.

[14] Tracy, David (1996). Blessed Rage for Order: The New Pluralism in Theology, (University of Chicago Press: Chicago).

[15] Weissman, Gary. Fantasies of Winessing: Postwar Efforts to Experience the Holocaust (Cornel Univ Press: Ithaca and London) 2004.

[16]Wiesel, Elie (2006). Night, tr. Marion Wiesel. (Hill and Wang: New York).

\section{Acknowledgment:}

This paper was written under the project "Women's Excellence in Scientific Research and Project Management" EXCELENTFEM, Financed by the R014 Program "Research in Priority Areas" EEA Financial Mechanism 2009-2014, contract 22BIL31.03.2017 